\title{
CAPITAL MOBILITY IN SUB-SAHARAN AFRICA: A PANEL DATA APPROACH
}

\author{
ALBERT H. DE WET ${ }^{1}$ AND RENEE VAN EYDEN ${ }^{2}$
}

\begin{abstract}
In this paper we are primarily concerned with assessing the degree of capital mobility in sub-Saharan Africa. Using the methodology as proposed by Feldstein and Horioka (1980) - later termed the "Feldstein-Horioka puzzle" - we test the hypothesis of perfect capital mobility against the alternative of imperfect capital mobility. Following Vamvakidis and Wacziarg (1998) and Isaksson (2000), provision is made in our model to show the dependency of the lesser-developed countries on international finance and aid and how a more open economy contributes towards improving the level of capital movement in these countries. We also assess the change in the degree of capital mobility over the time period in an effort to see whether institutional and political changes have been successful. We show that, compared to the region, South Africa is, to a large extent, more developed and should therefore play a leading role in the "African Renaissance".

Stationary panel data estimation techniques are applied to a sample of 36 sub-Saharan African countries over the time period 1980-2000. The benefits of using one-way error component models are derived from simultaneously employing time and cross-section dimensions of the data, resulting in a substantial increase in the degrees of freedom. The fixed and random effects models enable us to acknowledge country heterogeneity within the panel, making provision for differences across countries like capital control policies, financial and capital market structures and exchange rate regimes. JEL Classifications: C23, 016, 055. Keywords: Capital mobility; sub-Saharan Africa; Panel data.
\end{abstract}

SINCE THE LATE SEVENTIES it has increasingly been assumed that financial markets are highly integrated, giving capital and other assets the opportunity to move unobstructed between countries. Numerous institutional and political changes have been implemented in order to increase the mobility of capital to levels proposed by economic theory. More recently, the effect of globalisation and the technology and information revolution did not only render financial transactions more efficient, but has also broken down geographic boundaries that previously prevented the free flow of capital amongst countries.

To assess the level and the driving forces behind capital mobility in the sub-Saharan African region, we use the methodology as proposed by Feldstein and Horioka (1980). Their model is based on the simple goods market equilibrium equation and measures the extent to which a higher domestic saving rate is associated with a higher rate of domestic investment. If capital is indeed very mobile, the relationship between saving and investment should be weak and conversely, if capital is rather immobile, investment rates should correspond closely to saving rates.

Although the original Feldstein-Horioka based studies were mainly time-series or

\footnotetext{
${ }^{1}$ Tax Policy Chief Directorate, National Treasury.

2 Department of Economics, University of Pretoria. The authors would like to thank two anonymous referees for comments on earlier drafts of the paper.
} 
cross-section studies, we use a panel data estimation approach. It is common knowledge that data problems are very prevalent for African countries but because panel estimation techniques make use of both the time and cross-section dimensions of the data, we increase the number of observations beyond that of a pure time-series or cross-section study. Furthermore, the ability of panel data estimation techniques to acknowledge cross-section specific effects would also yield better and more representative estimation results. These fixed or random effects may represent unobservable factors like different economic policies being followed, different capital control measures and any other time invariant countryspecific factor that is not easily observable but may still be significant in determining the saving-investment relationship.

\section{THE FELDSTEIN-HORIOKA APPROACH: THEORY AND CRITIQUE}

Feldstein and Horioka (1980) devised a simple model based on the goods market equilibrium condition in an attempt to explain the degree of capital mobility. The paper measures the extent to which a higher domestic savings rate is associated with a higher rate of domestic investment. With perfect capital mobility, the relationship between saving and investment should be very weak. Conversely, if capital is rather immobile, investment rates should correspond closely to saving rates. Therefore, to assess the relationship between saving and investment rates they estimated an equation of the form:

$$
\left(\frac{I}{Y}\right)_{i}=\alpha+\beta\left(\frac{S}{Y}\right)_{i},
$$

where $(I / Y)$; is the gross domestic investment to gross domestic product ratio in country $i$ and $(S / Y)$ i the corresponding ratio of gross domestic saving to gross domestic product..

With perfect capital mobility, the value of $\beta$ should be small and tend to zero if a country is infinitely small relative to the world economy, while for a large country, the value of $\beta$ would be of the order of magnitude of the country's share of total world capital. Estimates of $\beta$ close to unity would indicate that most of the incremental saving in a country has remained there, i.e. saving and investment in a country are highly correlated. Therefore, the finding of a high value of $\beta$ would pose strong evidence against the hypothesis of perfect capital mobility. It is important to note that provision is made for open economies in the national goods market equation, and that saving and investment need not be equal in a specific period within a country because of international capital flows. This implies that it would be highly unlikely that the coefficient $\beta$ would be exactly equal to unity, i.e. there is no movement of capital between countries.

When estimating the equation for a sample of 16 OECD countries for the period 19601974, Feldstein and Horioka (1980:321) found the $\beta$ coefficient to be between 0.89 and 0.94 . These estimated coefficient values contradicted the prior expectations of near perfect capital mobility in the selected OECD countries, especially because of the fact that this period was charaterised by the many efforts made by countries to enhance the interaction of global capital markets. Although perfect capital mobility may be perceived in the short run, there appeared to be sufficient elements, rigidities and 
preferences to keep saving invested in the country of origin.

It is not surprising that the economic profession received the contradictory evidence of the Feldstein-Horioka (1980) paper with a sense of shock. After the collapse of the Bretton Woods system in the early 1970s, institutional and capital controls rapidly retreated and a feeling developed amongst economists and politicians alike that it was only a matter of time before the world would come to resemble the models of perfect capital mobility already dominating international economic theory. The economic profession was provoked into response. Firstly, the Feldstein-Horioka evidence was alleged to have ignored the fact that the whole discipline regarding capital mobility issues had been based on misleading principles; and secondly, the results seemed to be contradicting the intuitive reasoning of policy makers in that era, which had been dominated by attempts to dismantle existing capital controls and to generate a global market. The response took several forms but can mainly be categorised into two groups (Watson 2001:83). Firstly, those who attacked the Feldstein-Horioka methodology, and argued that the strong relationship indicated by the coefficient was attributed to bad econometric modeling. Secondly, there were those who attacked the link that Feldstein and Horioka drew between the savings and investment coefficient and imperfect capital mobility. They argued that evidence of a strong link between the former did not necessarily imply evidence for the latter.

The first line of criticism was dismissed fairly quickly. Although most influential reviews of the literature on the Feldstein-Horioka puzzle have described the continuing high savinginvestment correlation as 'upsetting' for the conventional wisdom of perfectly integrated capital markets (Frankel 1991:227); at the same time, such high correlations have also been described as 'remarkably consistent' (Glick and Rogoff 1995:159) and 'extremely robust' (Baxter and Crucini 1993:417; Sarno and Taylor 1998:20). Therefore, whatever the methodological weaknesses of the Feldstein-Horioka study may be, various other authors have replicated their results and supported their methodology.

The more interesting debate surrounding the Feldstein-Horioka puzzle is whether the saving-investment correlation can indeed be used to measure the extent of capital mobility. Indeed, the aim of much of the literature, following the Feldstein-Horioka tradition, has been to show that a strong relationship between saving and investment do not necessarily violate the assumptions of a perfectly integrated capital market. However, for the saving-investment coefficient to approach zero, as implied in a world of perfect capital mobility, three separate conditions would have to hold as set out in the article of Dooley, Frankel and Mathieson (1987). Firstly, a country's investment rate should depend solely on domestic interest rates. Secondly, domestic interest rates would have to converge to a world norm, and thirdly, there should be no difference between countries regarding the expected return on investment and saving. If we look at each of these conditions in isolation, one can see that they resemble a "textbook" type of world. The fact that they are separately unlikely to occur almost rules out the possibility that they would be obtained simultaneously; therefore, a world of perfect capital mobility is highly unlikely (see Dooley et al. 1987:505). If any of the conditions fail to hold, no reason exists for the correlation between saving and investment to disappear. It is clear that evidence regarding capital mobility is much more ambiguous than is implied by the certainty with which assumptions of perfectly integrated capital markets have been made and are still being made in public (Watson 2001:84). 


\section{LITERATURE REVIEW}

The Feldstein-Horioka relationship has been studied and tested using cross-section, timeseries and panel data analysis, without any clear-cut answer to the level of capital mobility on international markets. We confine ourselves in the review that follows mainly to those studies that have explicitly used cross-section and panel data methods, as the latter is the methodology that we employ in our analysis.

Following the earlier results, Feldstein (1983) once again estimated the relationship for 17 OECD countries for the period 1974-1979. The slope coefficient of 0.86 corresponded to that obtained by Feldstein and Horioka (1980). In contrast, Summers (1985) argued that the high correlation does not necessarily signal low capital mobility, stating that if cross-country policies and targets were similar, there would undoubtedly be a high correlation between saving and investment across countries. Measurement errors may also lead to a downward bias of the correlation between saving and investment in middle and low-income countries, as official data do not always take into account the economic activities of the informal sectors.

Dooley et al. (1987) used a combination of 14 industrialised and 50 developing countries from around the world, and found that a close relationship between domestic saving and domestic investment does exist and that it is a robust empirical regularity, concluding that their results cast doubt on the view that capital markets are integrated. For developing countries the regularity was not that apparent. They attributed this to these countries' dependence on foreign aid to finance their current-account imbalances. Estimating the relationship using total domestic saving and investment for 10 OECD countries for the period 1965-1986, the results of Bayoumi (1990) supported that of Feldstein and Horioka (1980) and indicated that the slope coefficient dropped over time, implying that financial deregulation has improved capital mobility. Using samples of 45 developing countries for the period 1975-1981, Wong (1990) indicated that the choice of sample has an important effect on the saving-investment correlation. His results varied from a statistically insignificant 0.08 to a significant parameter of 0.61 , depending on the specific countries included. He also showed that countries with extensive capital controls have a higher saving-investment correlation. Frankel $(1991 ; 1992)$ indicated that a high correlation between saving and investment ratios does not necessarily signal a low degree of financial integration. Firstly, the co-movement of savings and investment may be driven by other economic factors. Along with Obstfeld (1985), he argues that a factor such as population growth could be the underlining determinant of the correlation. Such factors would account for the observed high correlation even if capital markets were indeed open. However, Feldstein and Bacchetta (1991) showed that the Obstfeld hypothesis did not hold for industrialised countries and that the expected factors did not explain the high saving-investment correlation.

Since both financial and goods markets are well integrated inside a country, Bayoumi and Rose (1993) took an alternative approach by using regional saving and investment data within the United Kingdom. They found a relatively low estimated coefficient, which supported the Feldstein-Horioka hypothesis. Dekle (1995) found supporting results when performing the same analysis on private saving and investment data for Japan.

Vamvakidis and Wacziarg (1998) were amongst the first authors to apply the panel data approach to the Feldstein-Horioka puzzle. When estimating the saving-investment 
relationship, they found that the Feldstein-Horioka results only hold for OECD countries and vanish when using any other sample of countries. Based on the period 1970-1993 they indicated that if middle- and low-income countries are included in the sample of countries, the strong correlation between saving and investment does not hold. This panel estimation once again showed that OECD countries displayed a larger coefficient than the developing countries. For the 'All developing countries' category (a total of 83 countries) the coefficient ranged from 0.14 to 0.39 . Vamvakidis and Wacziarg ( $p p$. cit) pointed out that the conventional wisdom that points to a strong relationship between investment and saving rates is therefore contradicted in the context of developing countries. To justify their results, they argue that if cross-country heterogeneity drives capital flows according to the factor endowment theory, we should experience little capital flows between countries that are similar with respect to factor endowments. Therefore, as the sample size increases and more countries are included, which are more diverse regarding factor endowments, the savinginvestment relation should fall. An odd observation was that the slope coefficient increased as the level of income increased. The authors attributed this to the sensitive effects that both foreign aid and debt repayment have on saving and investment, which would strengthen the correlation between the variables. Vamvakidis and Wacziarg (op. cit) argue that a large source of capital flows in middle- and low-income countries may well be attributed to financial and capital aid supplied to these countries. It is often the case in these countries that aid inflows and outflows are relatively large relative to the size of domestic investment and savings. Hence, these aid type capital flows might drive much of the empirical findings regarding savings and investment in developing countries.

Isaksson (2000) employed the Feldstein-Horioka methodology and set out the main objective in his paper to gauge the degree of international capital mobility between developing countries. However, he also tried to determine whether financial market liberalisation has led to increased international capital mobility. He did make one important extension to the Feldstein-Horioka equation namely to include the effects of foreign aid in the estimation equation. Hanson (1992) and Montiel (1994) argue that when estimating the saving-investment relationship, the effects of foreign aid must also be taken into account. In many developing countries investment does not only depend on the saving rate but also on the extent to which foreign aid is used for investment. Ignoring foreign aid in such circumstances would therefore render the Feldstein-Horioka relationship mis-specified. Furthermore, if only part of the foreign aid is indeed used for investment and the rest, for example, goes towards increased consumption, the measured saving rate would decrease and the coefficient of the savings rate would be downwardly biased, indicating more capital mobility than is indeed the case for the specific countries. Isaksson (op. cit) therefore includes foreign aid in the estimation in order to attain a better estimate of the savinginvestment relationship and a dummy variable to determine to what extent the saving coefficient has changed over time and to see whether financial liberalisation within the period has caused capital mobility to increase. The results indicated that capital mobility is low and that financial liberalisation improved access to international capital markets. The results are relatively inconsistent with various other studies that almost consistently indicated a high level of capital mobility in developing countries. The inclusion of foreign aid in the estimation regression is regarded as the major contributor towards a higher saving-investment relationship. 
It is clear that regarding developed countries there is support for the Feldstein and Horioka results, which indicates that financial markets are not as much integrated as would be expected. When the saving-investment relationship is tested using developing countries, the Feldstein-Horioka hypothesis of very limited capital market integration disappears. Once again this is rather contradicting prior expectations, as one would assume that rigidities within the financial system of developing countries would make capital less mobile. The contribution of foreign aid is emphasised by many researchers as an important factor influencing the saving-investment relationship in developing countries and may even be the driving force behind investment in these countries.

\section{DATA DESCRIPTION}

To investigate capital mobility in the sub-Saharan African region we employ a panel of 36 countries for the time period 1980-2000. When estimating relationships amongst variables it is customary to use variables in real terms, converted to a common denomination. The benefit of panel data estimation, and in particular the fixed effects technique, is that it is able to acknowledge country-specific heterogeneity. In order to preserve these country-specific effects, the data series for each country is used in local currency. Since all estimations are performed on ratios, and since implicit consumption and investment deflators are not always available for the developing countries in the sample, we have opted to work with ratios in nominal terms. All data series were obtained from the World Bank Development Indicators. For a list of variable and country names used and included in the sample the reader is referred to Tables $\mathrm{Al}$ and $\mathrm{A} 2$ in Appendix A.

Testing for unit roots in time-series studies is standard practice amongst applied researchers and has become an integral part of any econometric study. However, testing for unit roots in panel data is more recent. To assess the degree of integration in our panel of data we employ the IPS unit root test as presented by Im, Pesaran and Shin (1999). This specific test has been chosen over those presented by Levin and Lin (1992) and Maddala and Wu (1999) because it has better small sample properties and is more intuitive in its construction than the Levin and Lin (1992) test and also does not require Monte Carlo simulation-based pvalues like the Madalla and Wu (1999) test. Application of the IPS test has rendered all variables stationary in levels, allowing us to employ stationary panel data techniques.

\section{ESTIMATION RESULTS}

To assess the level of capital mobility in sub-Saharan Africa we estimate the equation of the form

$\frac{I}{Y}_{i t}=\alpha_{i t}+\beta_{1} \frac{S}{Y_{i t}}+\beta_{2} \frac{C A}{Y_{i t}}+\beta_{3} \frac{A i d}{Y}+\beta_{4} \operatorname{Open}_{i t}+\beta_{5} \tau_{i t}+\beta_{6} \delta_{i t}+\varepsilon_{i t}$

where $(I / Y)_{i t}$ is the ratio of gross domestic investment to gross domestic product in country $i$ at time $t$, with $(S / Y)_{i t},(C A / Y)_{i t}$, and $(A i d / Y)_{i t}$ the corresponding gross domestic saving, the current account and financial aid to gross domestic product ratios. By including both the current account and the aid variable, we are not only capturing the effects of foreign aid on saving behaviour but we also make provision for foreign investment funds induced by the current account. Where previous studies have only 
included either the current account or the aid variable in the model in fear of multicollinearity, it was possible for us to avoid this problem, as the correlation between the two variables in our sample is very weak. This implies that by excluding either of the two variables, misspecification bias is actually introduced into the specification. Once again, the inclusion of the openness variable is important, as it could have a significant positive effect on the ability of capital to move. Our model specification further encompasses all previous studies in that it makes provision for two interactive dummy variables; $\tau$ and $\delta$. The South African interactive dummy $(\tau)$ is constructed by multiplying the saving rate of each country by a South African dummy variable that aims to acknowledge the fact that South Africa may have a different level of capital mobility and saving behaviour than the rest of the subSaharan African region. In a sub-Saharan African context, South Africa can be regarded as a "developed" country and could therefore bias the saving rate coefficient of the rest of the region upwards if we do not control for this difference. If significant, the actual savings rate coefficient for South Africa would be the sum of $\beta_{7}$ and $\beta_{5}$. The time interactive dummy $(\delta)$ is constructed by multiplying a time trend with the saving rate of each country. Similar to Isaksson (2000) this dummy variable will capture the change in the savings rate for the time period in order to evaluate the effectiveness of policy and institutional changes aimed at improving capital mobility. A negative value for $\beta_{6}$ would imply that the saving rate decreases each year i.e. policy changes are effective and capital is becoming more mobile in each time period with the opposite being true for a $\operatorname{pos} \beta_{6}$. e value of The country heterogeneity is captured by the country-specific coefficient $\alpha_{i t}$

The panel data estimation results for the pooled, fixed effects ${ }^{1}$ and random effects models are presented in Table 1. White heteroscedastic-consistent standard errors and covariances were used to correct for the presence of heteroscedasticity. Following the method proposed by Baltagi (2001:82-83), we also corrected the estimated model for serial correlation. Performing these corrections, it became apparent that even after a number of iterative corrections, the problem persisted. Both the panel LM and DW test statistics for serial correlation (see Baltagi 2001:95) assume a common correlation coefficient $(\rho)$ under $\mathrm{H}_{0}$. This implies that the test is assuming the individual rho's to

be the same for each cross-section and that the panel has the same degree of serial correlation across the cross-sections i.e. the serial correlation is homogenous across all countries. Studying the individual cross-section rho's, however, it became apparent that this is not the case. Similar to the estimation process where we acknowledged heterogeneity between the cross-sections, we once again acknowledge it when testing for serial correlation. The intuition is, therefore, that because of the fact that we perceive the serial correlation to be heterogeneous, we have to treat and test for it individually. We therefore corrected the data as proposed by Baltagi (2001:82-83) (also see Pindyck and Rubinfeld 2001:258-259) using the individual cross-section rho's and calculating individual DW test statistics, instead of using the pooled LM or DW test procedure, thereby acknowledging the cross-section serial correlation heterogeneity. Although a small number of countries' DW statistics were in the undetermined area, we can conclude that after performing the necessary adjustments, our final estimation

${ }^{1}$ Fixed effects can either be estimated using the least square dummy variable (LSDV) or "within" estimator. 
models are free from serial correlation problems.

\section{(a) The Pooled Model}

The pooled estimation model is the most restrictive of all the specifications and does not acknowledge any cross-section heterogeneity within the sub-Saharan region, assuming a common intercept for the whole panel. The saving rate coefficient appears to be rather low at 0.314 , in line with similar studies on developing countries. The magnitude and negative sign for the current account ratio coefficient indicates that a substantial amount of funds have flown into the region. The significance of the aid ratio shows that it is an important source of finance for investment in the region while the openness variable supports the argument that a more open economy will be conducive to capital flows and higher investment rates. The insignificance of the South African interactive dummy in this model implies that there is no difference in the saving rate structure between South Africa and the rest of the region. The time interactive dummy indicates that the mobility of capital increased throughout the time period.

\section{(b) The Fixed effects model}

This fixed effects model acknowledges cross-section heterogeneity and assumes a different intercept for each country included in the sample. It achieves this by including a matrix of dummies in the estimation in the case of the LSDV estimator. In the case of the "within" estimator, cross-section effects are "wiped out", essentially estimating the same coefficients but running the regression through the origin. Fixed effects are in this case calculated by means of the first order conditions of least squares. Estimated coefficients are however the same, hence we only report the result from the LSDV estimation in Table 1 and Appendix B.

The presence of these effects is apparent since the $F$ test for fixed effects (see Baltagi 2001:14) clearly rejects the null hypothesis of homogeneous cross-sections. These fixed effects may represent differences in political, institutional and economic policy systems that are not explicitly included in the specification, but which is accounted for when estimation is done, ultimately leading to more renresentative estimates. This is evident from the fact that this model has the highest adjusted $R^{2}$ value of 0.834 . For this reason we regard this model as our most representative and robust model specification.

The saving rate coefficient of 0.349 is similar to that of the pooled model and would in the Feldstein-Horioka framework potentially imply a relatively significant degree of capital mobility in the region. The time interactive dummy shows that the changes that took place in terms of financial deregulation within the time period were successful in increasing the level of capital mobility. Once again the current account ratio coefficient indicates that investment funds have flown into the region while financial aid remains an important determinant of investment. The significance of the South African dummy indicates that there is a difference in the saving structure of South Africa from the rest of the region with an individual coefficient estimate of $0.568(0.349+0.219)$. This higher value corresponds to previous studies in the literature that sets a high saving rate for developed countries. This model shows that based on the Feldstein-Horioka (1980) methodology, South Africa bears closer resemblance to more developed countries than the rest of the sub-Saharan African region.

(c) The Random effects model

The random effects model also acknowledges the cross section heterogeneity but 
differs from the fixed effect models in that it assumes that these effects are generated by a specific distribution. Therefore, this model assumes cross-section differences but do not explicitly model each effect. The loss in degrees of freedom, as is the case in the fixed effects models, is subsequently avoided. Once again, the LM test for random effects (see Greene 2000:572) clearly rejects the null of no cross-section heterogeneity in favour of the random effects specification.

The significant low saving rate coefficient of 0.286 would then potentially indicate even higher capital mobility in the region than the previous models and places more emphasis on financial aid to generate investment with the highest coefficient of all the models, namely 0.124. The time dummy shows that the degree of capital mobility has increased from 1980, while the capital account ratio coefficient indicates an inflow of investment fund into the region. Interestingly enough, although the model acknowledges cross-section heterogeneity, it does not indicate any difference in the savings rate coefficient of South Africa with that of the rest of the region.

Table 1. Capital mobility in the sub-Saharan Africa (1980-2000)

\begin{tabular}{|c|c|c|c|}
\hline & Pooled & Fixed effects & Random effects \\
\hline Constant & $\begin{array}{c}0.021 \\
(0.000)\end{array}$ & & $\begin{array}{c}0.030 \\
(0.000)\end{array}$ \\
\hline SR & $\begin{array}{c}0.314 \\
(0.000)\end{array}$ & $\begin{array}{c}0.349 \\
(0.000)\end{array}$ & $\begin{array}{c}0.286 \\
(0.000)\end{array}$ \\
\hline $\mathrm{CA}$ & $\begin{array}{r}-0.397 \\
(0.000)\end{array}$ & $\begin{array}{l}-0.360 \\
(0.000)\end{array}$ & $\begin{array}{l}-0.329 \\
(0.000)\end{array}$ \\
\hline Aid & $\begin{array}{c}0.101 \\
(0.000)\end{array}$ & $\begin{array}{c}0.065 \\
(0.005)\end{array}$ & $\begin{array}{c}0.124 \\
(0.000)\end{array}$ \\
\hline Openness & $\begin{array}{c}0.302 \\
(0.000)\end{array}$ & $\begin{array}{c}0.262 \\
(0.000)\end{array}$ & $\begin{array}{c}0.254 \\
(0.000)\end{array}$ \\
\hline SA dummy & $\begin{array}{r}-0.073 \\
(0.147)\end{array}$ & $\begin{array}{c}0.219 \\
(0.000)\end{array}$ & $\begin{array}{c}0.159 \\
(0.384)\end{array}$ \\
\hline Time durnmy & $\begin{array}{l}-0.006 \\
(0.044)\end{array}$ & $\begin{array}{r}-0.006 \\
(0.008) \\
\end{array}$ & $\begin{array}{r}-0.006 \\
(0.007) \\
\end{array}$ \\
\hline $\begin{array}{l}\text { Adjusted R2 } \\
\text { Fixed effects } \\
\text { Random effects }\end{array}$ & 0.773 & $\begin{array}{c}0.834 \\
\mathrm{~F}=8.613^{\text {**** }}\end{array}$ & $\begin{array}{c}0.668 \\
\mathrm{LM}=14.618^{\text {*kঝk }}\end{array}$ \\
\hline
\end{tabular}

Notes:

P-values reported in parentheses.

$* /(* *) /[* *]$ indicates significance of the coefficients or rejection of the null hypothesis on a $10 \% /(5 \%) /[1 \%]$ level of significance.

Country-specific fixed effects are reported in Appendix B.

To summarise, overall our estimation results of the saving-investment relationship are consistent with the empirical findings of previous studies. We are, however, cautious to conclude that the robust low saving rate coefficient of between 0.286 and 0.349 indicates a high capital mobility in the region as suggested by the Feldstein-Horioka methodology. Rather, we are of the opinion that a number of reasons could explain a different conclusion. Firstly, the sizable coefficients on the aid and current account ratios indicate the importance and dominance of aid and FDI flows in determining investment in the region, while a more open economy also enhances capital movements and investment rates. Secondly, it is difficult to quantify and control for the degree of measurement error in the data due to unrecorded informal activity in these countries, potentially leading to downward bias in the correlation between saving and investment. Moreover, similar to Hansen (1992) and Montiel (1994), one could argue that the increase in consumption of foreign aid decreases the saving rate within these countries, 
exaggerating the downward bias of the saving rate coefficient.

The consistently negative time interactive dummy may however be interpreted as an indication that institutional changes and policy aiming at financial deregulation has been successful. Our results also confirm that South Africa displays developed country characteristics with a higher saving rate coefficient than the rest of the region.

\section{POLICY IMPLICATIONS}

From a macroeconomic policy perspective, our results suggest that taxes levied on domestic and foreign investment require special scrutiny. If taxes on capital investments are relatively high compared to the rest of the world, investors would demand higher yields on their investments, or simply extract funds and invest it in countries with better yield prospects. Government expenditure programmes should not only be aimed at improving living conditions for the poor but should also be aimed at improving and building financial and institutional infrastructures in efforts to generate domestic savings. Monetary autonomy, transparency and consistency are essential in creating investor confidence. As with fiscal policy, monetary authorities should not only create the environment to attract foreign capital into the region by setting international competitive real interest rates, but they should also create opportunities through which investment can be easily funded by domestic saving.

In the light of the establishment of the African Union (AU) and the launch of the New Partnership of Africa's Development (NEPAD), one can look at how our empirical findings would influence the objectives and strategic policy framework of these movements. The AU will replace the Organisation of African Unity (OAU) and differs from the OAU in that it would have the capacity to improve the economic, political and social development of the African people. The AU will also help ensure that the African continent is prepared to deal with the challenges of the $21^{\text {st }}$ century and to achieve the ultimate goal of African Unity. The New Partnership for Africa's Development is an Africa-specific development programme. The Partnership is a commitment by African Leaders to overcome poverty and to place the African continent on a path of lasting growth and development. NEPAD is therefore a stepping-stone towards creating a true African Union. In the strategic policy framework of NEPAD the three main pillars for success are development requirements like peace, security, democracy and political and regional integration; the development of priority sectors and variables like infrastructure, information and communications technology, human capital and capacity development and export diversification and promotion. The last pillar is the mobilisation of resources, both physical and financial in nature.

In order to stimulate growth and development, increasing savings and capital flows via debt relief, increasing Official Development Assistance (ODA) inflows and private capital, as well as better management of public revenue and expenditure, are suggested (Department of Foreign Affairs, South Africa 2002). Our empirical findings suggest that the channel through which international funds and capital can flow is to a large extent already in existence, with most of the countries relying heavily on foreign capital to finance their investments. The significance of the inclusion of the Aid variable into any of the estimation equations proves that it is a major contributor to investment in the region. It is therefore essential that the region is able to attract financial aid from world organisations like the International Monetary Fund and the World Bank. The challenge, 
however, is to increase the net inflow of capital into the region and channelling these funds to growth enhancing activities. Once again, this boils down to efficient and credible fiscal and monetary policy that would increase investor confidence and improve the investment environment. According to Basu, Calamitsis and Ghura (1999), for optimal resource allocation governments should focus on delivering essential public services and basic infrastructure, as well as promoting human resource and social development. There should also be a move towards implementing growth-conducive structural reforms and privatisation programmes. By enhancing financial sector sophistication, domestic savings will be stimulated and foreign investments attracted to the region.

Our results also suggest that South Africa has a major role to play in this development process. Displaying more developed country characteristics relative to other countries in the region, South Africa must lead the way and act as a role model for other countries' governments and institutions.

\section{CONCLUSION}

In this study we used panel data estimation techniques to assess the level and driving forces of capital mobility in the sub-Saharan African region. Due to the fact that these techniques incorporate both time-series and cross-section dimensions of the data, we increased the degrees of freedom of the estimation, generating more representative coefficient estimates. Another important reason for using these techniques is the fact that we were able to acknowledge country heterogeneity, therefore capturing unobservable country-specific effects, once again resulting in superior estimates.

Our estimation results have shown that, based on a variety of specifications using panel data econometric techniques, sub-Saharan African countries display a low saving rate coefficient within the Feldstein-Horioka framework, which confirms results of previous empirical studies. Our model specification however encompasses previous studies by including two interactive dummy variables to acknowledge that South Africa may have a different level of capital mobility and saving behaviour than the rest of the sub-Saharan African region, as well as the fact that capital mobility may be changing over time.

Our empirical results show that within the Felstein-Horioka framework, capital can indeed be regarded as increasingly becoming more mobile through the years as a result of institutional and political reforms. A more open economy is also conducive to higher levels of investment. South Africa can be regarded as a "developed" country within the region with a different saving and investment structure than the rest of the countries. An alarming finding is the fact that the investment rate of these countries is very dependent and largely influenced by foreign finance and aid which shows that these countries are not able the generate enough saving domestically to satisfy their investment needs. 
APPENDIX A

Data series and countries used in estimation

Table A1. List of variables

\begin{tabular}{ll}
\hline Series & Description \\
Aid & Net official development aid (ODA) from all donors as a ratio of gross domestic product \\
$\mathrm{CA}$ & Current account balance as a ratio of gross domestic product \\
IR & Gross capital formation (Gross domestic investment) as a ratio of gross domestic product \\
Open & Measurement of the degree of openness of the economy to international trade calculated as $(X / G D P+(Z / G D E)) / 2$ \\
SR & with $X$ and $Z$ total exports and imports and $G D E$ gross domestic expenditure \\
\hline
\end{tabular}

Table A2. List of countries included in the sample

\begin{tabular}{llll}
\hline Country & Abbreviated name & Country & Abbreviated name \\
Benin & Ben & Mali & Mali \\
Botswana & Bots & Mauritania & Mrita \\
Burkina Faso & Burk & Mauritius & Mrits \\
Burundi & Buru & Mozambique & Moz \\
Cameroon & Cam & Namibia & Nam \\
Central African Republic & CAR & Republic of Congo & RC \\
Chad & Chad & Nigeria & Nga \\
Comoros & Como & Niger & Nigr \\
Cote d'Ivoire & CotI & Rwanda & Rwa \\
Ethiopia & Eth & Sao Tome and Principe & STP \\
Gabon & Gab & Senegal & Sen \\
Gambia & Gam & Seychelles & Sey \\
Ghana & Gha & South Africa & RSA \\
Guinea-Bissau & Guib & Swaziland & Swz \\
Kenya & Ken & Togo & Togo \\
Lesotho & Les & Uganda & Uga \\
Madagascar & Mad & Zambia & Zam \\
Malawi & Mal & Zimbabwe & Zim \\
\hline
\end{tabular}

APPENDIX B

Country specific fixed effects

Table B1. Capital mobility in the sub-Saharan Africa (1980-2000)

\begin{tabular}{|c|c|c|c|c|}
\hline \multicolumn{5}{|c|}{$\begin{array}{l}\text { Dependent Variable: IR } \\
\text { Method: GLS (Cross Section Weights) } \\
\text { Sample: } 19802000 \\
\text { Total panel (unbalanced) observations: } 755 \\
\text { White heteroskedasticity-consistent standard errors \& covariance }\end{array}$} \\
\hline Variable & Coefficient & Std. Error & t-Statistic & Prob. \\
\hline SR & 0.349229 & 0.035847 & 9.742257 & 0.0000 \\
\hline $\mathrm{CA}$ & -0.359850 & 0.021499 & -16.73776 & 0.0000 \\
\hline Aid & 0.064655 & 0.018453 & 3.503678 & 0.0005 \\
\hline Open & 0.262376 & 0.023538 & 11.14691 & 0.0000 \\
\hline SA dummy & 0.219129 & 0.052356 & 4.185344 & 0.0000 \\
\hline Time dummy & -0.006448 & 0.002435 & -2.647419 & 0.0083 \\
\hline _BEN--RHO_BEN & 0.083160 & 0.007201 & 11.54823 & 0.0000 \\
\hline _BOTS_RHO_BOTS & 0.045851 & 0.020786 & 2.205867 & 0.0277 \\
\hline _BURK--RHO_BURK & 0.131788 & 0.007319 & 18.00715 & 0.0000 \\
\hline _BURU--RHO_BURU & 0.141846 & 0.012794 & 11.08720 & 0.0000 \\
\hline _CAR-RHO_CAR & 0.014280 & 0.013297 & 1.073866 & 0.2832 \\
\hline _CAM--RHO_CAM & 0.085470 & 0.010388 & 8.228112 & 0.0000 \\
\hline _CHAD-RHO_CHAD & 0.052994 & 0.012244 & 4.328356 & 0.0000 \\
\hline _COMO-RHO_COMO & 0.052723 & 0.029250 & 1.802471 & 0.0719 \\
\hline _RC-RHO_RC & -0.000172 & 0.089566 & -0.001919 & 0.9985 \\
\hline _COTI-RHO_COTI & -0.010663 & 0.005087 & -2.096220 & 0.0364 \\
\hline
\end{tabular}




\begin{tabular}{|c|c|c|c|c|}
\hline _COMO--RHO_COMO & 0.052723 & 0.029250 & 1.802471 & 0.0719 \\
\hline _RC--RHO_RC & -0.000172 & 0.089566 & -0.001919 & 0.9985 \\
\hline _COTI--RHO_COTI & -0.010663 & 0.005087 & -2.096220 & 0.0364 \\
\hline _ETH-RHO_ETH & 0.090335 & 0.006346 & 14.23526 & 0.0000 \\
\hline _GAB-RHO_GAB & 0.069393 & 0.032631 & 2.126605 & 0.0338 \\
\hline _GAM-RHO_GAM & 0.080341 & 0.018544 & 4.332453 & 0.0000 \\
\hline _GHA--RHO_GHA & 0.014543 & 0.006778 & 2.145538 & 0.0322 \\
\hline _GUIB--RHO_GUIB & 0.142987 & 0.037898 & 3.772967 & 0.0002 \\
\hline _KEN--RHO_KEN & 0.039427 & 0.005670 & 6.953289 & 0.0000 \\
\hline _LES-RHO_LES & 0.311220 & 0.064900 & 4.795379 & 0.0000 \\
\hline _MAD-RHO_MAD & 0.026826 & 0.009059 & 2.961180 & 0.0032 \\
\hline _MAL--RHO_MAL & 0.020069 & 0.020640 & 0.972313 & 0.3312 \\
\hline _MALI-RHO_MALI & 0.086000 & 0.006925 & 12.41863 & 0.0000 \\
\hline _MRITA-RHO_MRITA & 0.103924 & 0.018133 & 5.731165 & 0.0000 \\
\hline _MRITS-RHO_MRITS & 0.060728 & 0.017560 & 3.458246 & 0.0006 \\
\hline _MOZ--RHO_MOZ & 0.043481 & 0.006220 & 6.991057 & 0.0000 \\
\hline _NAM--RHO_NAM & 0.060497 & 0.040440 & 1.495965 & 0.1351 \\
\hline _NIGR-RHO_NIGR & 0.009956 & 0.013564 & 0.734021 & 0.4632 \\
\hline _NGA-RHO_NGA & 0.044528 & 0.012187 & 3.653804 & 0.0003 \\
\hline _RWA-RHO_RWA & 0.091719 & 0.003607 & 25.42677 & 0.0000 \\
\hline _STP--RHO_STP & 0.089057 & 0.069692 & 1.277859 & 0.2017 \\
\hline _SEN--RHO_SEN & 0.013536 & 0.002882 & 4.697275 & 0.0000 \\
\hline _SEY-RHO_SEY & 0.024668 & 0.033792 & 0.729984 & 0.4656 \\
\hline _SWZ--RHO_SWZ & 0.034138 & 0.013897 & 2.456468 & 0.0143 \\
\hline _RSA-RHO_RSA & -0.007910 & 0.010693 & -0.739768 & 0.4597 \\
\hline _TOGO-RHO_TOGO & 0.063183 & 0.015925 & 3.967488 & 0.0001 \\
\hline _UGA-RHO_ŪGA & 0.015078 & 0.001989 & 7.580533 & 0.0000 \\
\hline _ZAM--RHO_ZAM & 0.003194 & 0.012251 & 0.260726 & 0.7944 \\
\hline _ZIM-RHO_ZIM & 0.046085 & 0.006273 & 7.346079 & 0.0000 \\
\hline R-squared & 0.83385 & \multicolumn{2}{|c|}{ Mean dependent var } & 0.11875 \\
\hline Adjusted R-squared & 0.82430 & \multicolumn{2}{|c|}{ S.D. dependent var } & 0.09120 \\
\hline S.E. of regression & 0.03823 & \multicolumn{2}{|c|}{ Sum squared resid } & 1.04208 \\
\hline F-statistic & 87.2788 & \multirow{2}{*}{\multicolumn{2}{|c|}{ Durbin-Watson stat }} & 1.91895 \\
\hline Prob(F-statistic) & 0.00000 & & & \\
\hline
\end{tabular}

\section{REFERENCES}

BALTAGI, B.H. (2001). Econometric Analysis ofPanel Data, John Wiley and Sons Ltd., Chichester, England. BASU, A. , CALAMITIS, E. AND GHURA, D. (1999). Promoting Growth in sub-Saharan Africa, International Monetary fund. BAXTER, M. AND CRUCINI, M. (1993). Explaining Saving-Investment Correlations, American Economic Review, 83, 416-436. BAYOUMI, T. (1990). Savings-investment correlations. International Monetary Staff Paper, 37, 362-387.

AND ROSE, A. (1993). Domestic savings and mtra-national capital flows, European EconomicReview, 37, 1197-1202.

DEKLE, R. (1995). Savings-investment associations and capital mobility on the evidence of Japanese regional data, Journal of International Economics, 41, 53-72.

DEPARTMENT OF FOREIGN AFFAIRS, SOUTH AFRICA (2002). Basic Information: Birth of the African Union and the New Partnership for Africa's Development, $\underline{w w w . d f a . g o v .7 a / d o c s / a u e n g . h t m}$. 15 February.

DOOLEY, M., FRANKEL, J. AND MATHIESON, D. (1987). International Capital Mobility: What do Saving-Investment Correlations Tell Us?, International'Monetary Stafj"Papers, 34, 503-530.

FELDSTETN, M. AND HORIOKA, C. (1980). Domestic Saving and International Capital Flows, The Economic Journal, 90 , 314-329.

(1983). Domestic Savings and International Capital movements in the long run and in the short run. European

Economic Review, 21, 129-151.

AND BACCHETTA, P. (1991). National savings and international investment. In: Bernheim, D., Shoven, J. (Eds.),

'National Savings and Economic Performance. Chicago University Press, Chicago, 201-220.

FRANKEL, J. (1991). Quantifying International Capital Mobility in the 1980's, Chicago: University of Chicago Press, Chicago, 227-254.

(1992). Measuring International Capital Mobility: a Review, AEA Papers and Proceedings, 82(2).

GLICK, R. AND ROGOFF, K. (1995). Global Versus Country-specific Productivity Shocks and The Current Account,

Journal of Monetary Economics, 35, 159-192.

GREENE, W.H. (2000). Econometric analysis, Fourth Edition, New Jersey: Prentice Hall.

HANSON, J. (1992). An Open Capital Account: a brief Survey of the Issues and The Results. World Bank Poliy Research Working Paper, 901, The World Bank, Washington, D.C.

IM, K., PESARAN, M. AND SHIN, Y. (1999). Dynamic Linear Models for Heterogeneous Panels, Mimeo, Department of Applied Economics, University of Camebndge.

ISAKSSON, A. (2000). Financial liberalization, foreign aid, and capital mobility: evidence from 90 developing countries, Journal of International Financial Markets, Institutions and Money, 11, 309-338.

LEVIN, A. AND LIN, C. (1992). Unit Root Tests in Panel Data: Asymptotic and Finite Sample Properties, Department of Economics, University Of California at San Diego, Discussion Paper no. 92-93 (revised 1993). 
MADDALA, G. AND WU, S. (1999). A comparative study of unit root tests with panel data and a new simple test, Oxford Bulletin of'Economics and Statistics, 61, 631-652.

MONTIEL, P. (1994). Capital mobility in developing countries: some measurement issues and empirical studies. World Bank Economic Review, 8, 311-353.

OBSTFELD, M. (1985). Capital Mobility in the World Economy: Theory and Measurement, Carnegie Rochester Conference Series in Public Policy, 24, 55-104.

PINDYCK, S. AND RUBINFELD, D. (2001). Econometric Models and Economic Forecasts, Irwm/McGraw-Hill, Singapore. SARNO, L. AND TAYLOR, M. (1998). Savings-Investment Correlations: Transitory Versus Permanent, The Manchester School Supplement, 17-38.

SUMMERS, L. (1985). Tax Policy and International Competitiveness, In: International Aspects of Fiscal Policy, University of Chicago Press, Chicago.

VAMVAKIDIS, A. AND WACZIARG, R. (1998). Developing countries and the Feldstem-Honoka Puzzle. International Monetary Fund Working Paper 98/2. International Monetary Fund, Washington, DC.

WATSON, M. (2001). International Capital Mobility in the Era of Globalisation: Adding a Political Dimension to the 'Feldstem-Honoka Puzzle', Journal of Politics, 21 (2), 81-92.

WONG, D. (1990). What do savings-investment relationships tell us about capital mobility?, Journal of Monetary Finance, 9 , 60-74. 